\title{
Çocuklarda böbrekte basit kist
}

\author{
Simple renal cyst in children
}

Berfin Uysal

Gönderilme tarihi:16.02.2021

Kabul tarihi:18.03.2021

Öz

Amaç: Erişkinlerde sık görülen ve ilerleyen yaş ile insidansı artan böbrek kistleri çocuklarda göreceli olarak nadirdir. Düşük malignite riski nedeni ile erişkinlerde takip önerilmeyen basit kistlerin çocuklardaki takibi ile ilgili uzlaşılmamıştır. Bu çalışmada basit böbrek kistinin tanısı, takibi ve izlemde karşılaşılabilecek sorunlara değinilmiştir.

Gereç ve yöntem: Basit böbrek kisti tanısı ile Aralık 2016-Aralık 2020 tarihleri arasında tek merkezden en az 1 yıl boyunca izlenmiş 18 yaş altı hastalar retrospektif olarak incelenmiş, hastaların demografik, klinik ve radyolojik verileri değerlendirilmiştir.

Bulgular: Yirmi yedisi erkek, toplam 48 hastanın tanı anında yaş ortalaması $87,96 \pm 54,82$ ay, ortalama takip süresi 29,72 $\pm 17,63$ ay olarak bulundu. Yirmi dokuz hastanın başvuru esnasında şikâyeti yokken (farklı endikasyonlar nedeni ile yapılan US'de farkedilen) 11 hastada karın ağrıSı, 4 hastada idrar yolu enfeksiyonu, 4 hastada enürezis mevcut idi. Otuz altı hastada tam idrar tetkiki normal, 5 hastada piyüri, 3 hastada hematüri, 1 hastada proteinüri, 3 hastada piyüri ve hematüri birlikteliği mevcut idi. Kistlerin \%41,7'si üst pol, \%27'si alt pol, \%31,3'ü mediorenal yerleşimli, 24 hastanın kisti sağ tarafta iken, 21 hastanın sol tarafta ve 3 hastanın bilateral

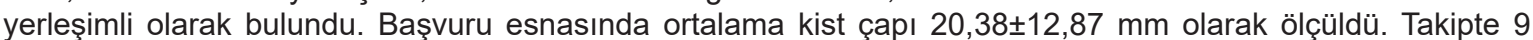
hastada kist boyutlarında artış görülürken, izlemde 1 hastanın kistinin kaybolduğu görüldü.

Sonuç: Sonuç olarak, ayrıntılı bir ultrasonografik inceleme ile tanı alabilecek evre 1 ve evre 2 basit böbrek kistlerinde malign dönüşüm ve cerrahi endikasyon gerekliliği nadiren görülse de, takiplerinde evre artışı, ODPKB hastalığı, hipertansiyon ya da böbrek fonksiyon bozukluğu gibi ortaya çıkabilecek durumlar nedeni ile izlemleri gereklidir.

Anahtar kelimeler: Çocuk, böbrek, basit kist.

Uysal B. Çocuklarda böbrekte basit kist. Pam Tıp Derg 2021;14:460-465.

\begin{abstract}
Purpose: Renal cysts, which are common in adults are relatively rare in children. Due to the low risk of malignancy, follow-up of simple renal cysts in adults is not recommended where as there is no consensus on the follow-up of children with simple renal cysts. In this study, diagnosis, folllow-up and the problems that may be encountered through the follow-up of simple renal cysts are discussed.

Materials and methods: Children under 18 years of age who were monitored at a single center for at least 1 year between 2016-2020 with the diagnosis of simple renal cyst were retrospectively examined and demographic, clinical and radiological data were evaluated.

Results: A total of 48 patients ( 27 boys) had a mean age of $87.96 \pm 54.82$ months at the time of diagnosis, and a mean follow-up period of $29.72 \pm 17.63$ months. Twenty-nine patients had no complaints at the time of admission, 11 patients had abdominal pain, 4 patients had urinary tract infection, and 4 patients had enuresis. Urinalysis was normal in 36 patients 5 patients had pyuria, 3 patients had hematuria, 1 patient had proteinuria, 3 patients had pyuria and hematuria. The cysts of 24 patients were located on the right side, 21 patients were located on the left side and 3 patients were located bilaterally, while $41.7 \%$ of the cysts were located in the upper pole $27 \%$ in the lower pole, $31.3 \%$ in the mediorenal. The mean diameter of the cyst at presentation was measured as $20.38 \pm 12.87 \mathrm{~mm}$. While an increase in the size of the cyst was observed in 9 patients, it was observed that the cyst of 1 patient disappeared in the follow-up.

Conclusion: Although malignant transformation and the necessity of surgical indication are rarely seen in stage 1 and stage 2 simple renal cysts that can be diagnosed with a detailed ultrasonographic examination, follow-up is required because of conditions that may occur such as increased stage, ADPKD disease, hypertension or renal dysfunction.
\end{abstract}

Key words: Children, kidney, simple cyst.

Uysal B. Simple renal cyst in children. Pam Med J 2021;14:460-465.

Berfin Uysal, Uzm. Dr. Dörtçelik Çocuk Hastalıkları Hastanesi, Çocuk Sağlığı ve Hastalıkları Çocuk Nefroloji Bilim Dalı, Bursa, Türkiye, e-posta: berfing@yahoo.com (https://orcid.org/0000-0001-6267-0454) (Sorumlu Yazar) 


\section{Giriş}

Erişkinlerde sık görülen ve ilerleyen yaş ile insidansı artan böbrek kistleri çocuklarda göreceli olarak nadirdir [1-3]. Radyolojik görüntülemenin yaygın kullanılması ile birlikte genellikle asemptomatik olan ve farklı endikasyonlar nedeni ile inceleme yapılırken fark edilen böbrek kisti tanısı giderek artmaktadır [4, 5]. Düşük malignite riski nedeni ile erişkinlerde takip önerilmeyen basit kistlerin çocuklardaki takibi ile ilgili uzlaşılmamıştır [6]. Pediyatrik yaş grubunda, böbrek kistleri genetik veya sendromik hastalıklara bağlı görülebilir ve literatürde böbrek fonksiyonlarında bozulma görülen basit kist tanılı hastalar bildirilmiştir [7, 8]. Bu hastaların prognozunu belirgin şekilde etkileyeceği için böbrek kistlerine ayrıntılı ve hassas bir bakış açısı önemlidir. Bu çalışmada merkezimizde basit böbrek kisti tanısı alan çocukların klinik özellikleri ve izlem sonuçları araştırımıştır.

\section{Gereç ve yöntem}

$\mathrm{Bu}$ çalışma, Bursa Dörtçelik Çocuk Hastanesi ve Bursa Şehir Hastanesi çocuk nefroloji polikliniklerinde Aralık 2016-Aralık 2020 tarihleri arasında böbreğin basit kisti tanısı ile en az 1 yıl süre boyunca izlenen 18 yaş altı çocuk hastaları kapsamaktadır. Multikistik displastik böbrek hastalığı (MKDBH), otozomal resesif polikistik böbrek hastalığı (ORPKBH) ve otozomal dominant polikistik böbrek hastalığı (ODPKBH) nedeni ile izlenen hastalar çalışmaya dahil edilmedi. İzlemlerinin sırasıyla 11. ve 23. aylarında ODPKBH tanısı alan iki hasta çalışma dışı bırakıldı.

Basit kist tanısı, ultrasonografik inceleme ile konmuş, US ile septasyon ve/veya kalsifikasyon saptanan veya izleminde kist boyutlarında artış saptanan hastalara manyetik rezonans (MR) görüntüleme yapılmıştır.

Basit kist; modifiye Bosniak sınıflamasında (Tablo 1) evre 1 ve evre 2 olarak isimlendirilen, düzgün sınırlı, ince duvarlı, ekojen odak içermeyen, homojen içerikli, kontrastlı görüntülemelerde kontrast tutulumu göstermeyen veya kist duvarında minimal kalınlaşma veya kanlanma göstermeyen ince septasyon (Doppler US ile teyid edilen) veya

Tablo 1. Modifiye Bosniak sınıflaması

\begin{tabular}{ll}
\hline Evre & Tanım \\
\hline I & Yuvarlak, düzgün, ince duvar yapısı. US ile görüntülemede ekojen odak yoktur. Su dansitesi ile \\
& uyumlu homojenite ve kontrastı BT ile boyanma olmaması. \\
II* & Duvarında veya septa(larında) hafif/düzgün kalınlaşma ile birlikte olan veya olmayan ince septalı \\
& kist. BT'de kalsifikasyon ve kontrast uygulaması sonrası boyanmama. Doppler US ile kist duvarı \\
& veya septasyonlarda akım saptanmaması. \\
& Kalın veya düzensiz septasyonlar. BT'de kalın/düzensiz kalsifikasyonlar. Kist veya septa duvarında \\
III & IV kontrast ile boyanma. Doppler US ile kist veya septa duvarında akım alınması. US bulguları evre \\
& 3'ü destekliyorsa, kontrastlı aksiyal görüntüleme yapılması mutlaka düşünumelidir. \\
& Kalın duvar, katı içerik veya nodüler alanlara sahip kistik kitle. Kontrast ile heterojen boyanma. \\
& Kist duvarı, septasyonlar, nodüler içerikte Doppler US ile akım alınması. US bulguları evre 4'ü \\
IV & destekliyorsa, kontrastlı aksiyal görüntüleme yapılması mutlaka düşünülmelidir. \\
\hline
\end{tabular}

Hem US hem BT/MR çekilip tutarsızlık olduğu durumda sınıflama için, kontrastlı aksiyal görüntüleme esas alınmalıdır. Böbrek kisti tanısı alan çocuklar böbreğin herediter kistik hastalıkları açısından değerlendirilmelidir.

${ }^{*} \mathrm{Bu}$ sınıflama sistemi ile ileri tecrübe kazanılıncaya kadar evre 2 kist olarak tanı alan çocuklar düzenli aralıklar ile değerlendirilmelidir. US; ultrasonografi, BT; bilgisayarlı tomografi, IV; intravenöz, MR; manyetik rezonans

minimal kalsifikasyon (bilgisayarlı tomografi ile teyid edilen) gösteren yapı olarak kabul edildi [9]. Her hastanın ebeveyn US'si değerlendirildi. Kan basıncı, ölçülen üç ortalama değer alınarak oskültasyon metodu ile ölçülerek, Amerikan Pediatri Akademisinin 2017 yılında güncellenen kılavuzuna göre değerlendirildi [10]. Hastaların böbrek fonksiyonları Schwartz formülü (eGFR=0,413 x boy/serum kreatinin $(\mathrm{mg} / \mathrm{dl})$ ) ile hesaplanarak glomerül filtrasyon hızı (GFR) $>90 \mathrm{ml} / \mathrm{min} / 1,73 \mathrm{~m}^{2}$ olması normal böbrek fonksiyonu olarak değerlendirildi [11].

İstatistiksel değerlendirmeler SPSS 24.0 (IBM Corp.; Armonk, NY, USA) yazılımı kullanılarak yapıldı. Tanımlayıcı istatistikler, ortalama, standart sapma, frekans tabloları tanımlandı. 
Çalışma için, Bursa Şehir Hastanesi Etik Kurulu'ndan onay alınmıştır.

\section{Bulgular}

Yirmi yedisi erkek, toplam 48 hastanın tanı anında yaş ortalaması $87,96 \pm 54,82$ ay olarak bulundu. Ortalama takip süresi $29,72 \pm 17,63$ ay idi. Yirmi dokuz hastanın başvuru esnasında şikayeti yokken (farklı endikasyonlar nedeni ile yapılan US'de fark edilen) 11 hastada karın ağrısı, 4 hastada idrar yolu enfeksiyonu, 4 hastada enürezis mevcut idi. Otuz altı hastada tam idrar tetkiki normal iken, 5 hastada piyüri, 3 hastada hematüri, 1 hastada proteinüri, 3 hastada piyüri ve hematüri birlikteliği mevcut idi (Tablo 2).
Obeziteleri de olan, kist çapları 18 ve $23 \mathrm{~mm}$ ölçülen 2 hasta hipertansif olarak değerlendirildi ve takiplerinde anti-hipertansif tedavi ihtiyaçları oldu.

Hastaların \%89,5'unda aile öyküsü yokken, 4 hastada anne veya babada böbrekte basit kist öyküsü alındı, 1 hastanın aile öyküsü bilinmiyordu. İzlemlerinde ODPKBH tanısı alan ve çalışma dışı bırakılan 2 hastanın aile öyküleri olmaması nedeni ile de novo mutasyon olarak değerlendirildi.

Kistlerin \%41,7'si üst pol, \%27'si alt pol, \%31,3'ü mediorenal yerleşimli, 24 hastanın kisti sağ tarafta iken 21 hastanın sol tarafta ve 3 hastanın bilateral yerleşimli olarak

Tablo 2. Hastaların demografik ve klinik özellikleri

\begin{tabular}{|c|c|c|}
\hline & & $\begin{array}{l}\text { Hasta sayısı } \\
\text { (n) }\end{array}$ \\
\hline \multirow[t]{2}{*}{ Cinsiyet } & $\mathrm{K} ı \mathrm{z}$ & 21 \\
\hline & Erkek & 27 \\
\hline Tanı yaşı (ay) & $87,96 \pm 54,82$ & \\
\hline Takip süresi (ay) & $29,72 \pm 17,63$ & \\
\hline \multirow[t]{4}{*}{ Başvuru şikayeti } & Yok & 29 \\
\hline & IYE & 4 \\
\hline & Karın ağrısı & 11 \\
\hline & Enürezis & 4 \\
\hline \multirow[t]{3}{*}{ Aile öyküsü } & Yok & 43 \\
\hline & Var & 4 \\
\hline & Bilinmiyor & 1 \\
\hline \multirow[t]{5}{*}{ TiंT bulguları } & Normal & 36 \\
\hline & Piyüri & 5 \\
\hline & Hematüri & 3 \\
\hline & Proteinüri & 1 \\
\hline & Proteinüri+Hematüri & 3 \\
\hline
\end{tabular}

IYE; İdrar yolu enfeksiyonu, TiT; Tam idrar tetkiki

bulundu. Başvuru esnasında ortalama kist çapı $20,38 \pm 12,87 \mathrm{~mm}$ olarak ölçüldü. Takipte 9 hastada kist boyutlarında artış görülürken izlemde 1 hastanın kistinin kaybolduğu görüldü. Başvuru esnasında 2 yaş 4 aylık olan bir erkek hastanın 26 ay izlem sonrası kontrol US'lerinde sol böbrek üst polde $10 \mathrm{~mm}$ çapında görülen basit kist yapısı görülmedi (Tablo 3 ).

Dört hastada kistte ince septasyon, 2 hastada minimal kalsifikasyon saptandı. Ultrasonografide ince septasyon ve kalsifikasyon saptanan 2 hastaya, ince septasyon saptanan 2 hastaya ve kist boyutlarında artış saptanan 3 hastaya MR görüntülemesi yapıldı. Bu hastaların MR görüntülemesindeki kist boyutları US görüntülemesindeki boyutları ile uyumlu, septasyonları ince ve yine kalsifikasyonları hafif idi, kistler Bosniak Evre 2 ile uyumlu olarak MR'da kontrast tutulumu göstermediler. 
Tablo 3. Radyolojik bulguların özellikleri

\begin{tabular}{lll}
\hline & & Hasta sayısı (n,\%) \\
\hline Kistin konumu & Üst pol & $20(41,7)$ \\
& Alt pol & $13(27)$ \\
Kistin tarafı & Mediyorenal & $15(31,3)$ \\
& Sağ & $24(50)$ \\
Başvuru sırasındaki kist çapı (mm) & Sol & $21(43,7)$ \\
Takipte kist boyutlarında artış & Bilateral & $3(6,3)$ \\
& $20,38 \pm 12,87$ & \\
Ince septasyon & Var & $9(18,7)$ \\
Kalsifikasyon & Yok & $38(79,2)$ \\
\hline
\end{tabular}

\section{Tartışma}

Erişkinlerde yaş ile artan böbrek kisti insidansı 40 yaşında \%20, 50 yaş ile birlikte $\% 50$ olarak bildirilmektedir [12, 13]. Böbrek kist yapısı ve malignite risk değerlendirmesi için erişkinlerde kullanılan Bosniak sınıflandırma sistemi böbrek kistlerinin bilgisayarlı tomografi ile radyografik özelliklerinin tanımlanmasına dayanır [14]. Pediyatrik yaş grubunda ise göreceli olarak daha nadir görülen böbrek kistlerinin insidansı $\% 0,2-\% 5$ arasında değişmektedir $[1,3,5,15]$. Fakat böbrek kistlerinin çocuk yaş grubunda kronik böbrek hastalığına, polikistik böbrek hastalığına, malign dönüşüme ve semptomatik büyümeye ilerleyen bir seyirde görülebilmesi özellikle basit böbrek kistinin ayırımını yapmak ve izlemek açısından önem taşımaktadır [5, 16-19]. Çalışmamızda değerlendirilen toplam 48 hastanın en az 1 yıl boyunca yapılan izlemleri boyunca 9 hastanın kist boyutlarında artış olduğu görülmüş fakat malign dönüşüm saptanmamıştır, yine 48 hastanın 7'sinin evre 2 kist ile uyumlu US bulgusu olduğu için görüntüleme intiyaçları olmuştur.

Çocuk hastanın iyonize radyasyona maruz kalmasını azaltmak amacı ile US bulguları ile tanımlanan modifiye Bosniak sınıflaması geliştirilmiştir. Wallis ve ark. [9] 8 yıl içinde en az 6 ay boyunca izlenmiş ve kompleks böbrek kisti tanısı almış 39 çocuk hastanın görüntülemeleri doğrultusunda modifiye Bosniak sınıflamasını önermişlerdir. Bu hastaların 18'i takipte sadece US ile izlenmiş, 21'ine ise ayrıca BT veya MR görüntülemesi yapılmıştır [9]. Henüz bu sınıflamayı doğrulayan prospektif çalışma olmamasına rağmen yapılan retrospektif çalışmalarda ultrasonografik olarak tanımlanan özellikle evre 1 ve evre 2 böbrek kistlerinin tanımlanmasının ve evre 2, 3 ve 4 kistler için ileri görüntüleme ve cerrahi endikasyon ihtiyacını belirtmesinin yeterli olduğu görülmüştür [1, 20-22]. Bizim çalışmamızda da US'de ince septasyon ve kalsifikasyon saptanan 2 hastaya, ince septasyon saptanan 2 hastaya ve kist boyutlarında artış saptanan 3 hastaya MR görüntülemesi yapıldı ve bu hastalar eşlik eden ince septasyon ve ince kalsifikasyonları nedeni ile evre 2 böbrek kisti olarak kabul edildi.

Böbrek kisti oluşumunun mekanizması net olarak bilinmemekle beraber yaşa bağlı nefron kaybı, hormonal ve çevresel etkenler sorumlu tutulmuş ve basit kistlerin erkeklerde daha sıklıkla görüldüğü belirtilmiştir [23]. Bizim çalışmamızda da Koutlidis ve ark.'nın [6] ve Eroğlu ve ark.'nın [8] çalışmalarına benzer şekilde erkek/kız oranı 1,28 ve kist lokalizasyonu literatür ile uyumlu olarak sıklıkla sağ böbrek üst polde bulundu $[6,8,22]$.

Eroğlu ve ark.'nın [8] yaptığı çalışmada tüm hastaların idrar analizleri normalken Bayram ve ark.'nın [22] çalışmasında bu oran \%84 olarak bulunmuştur $[8,22]$. Bizim çalışmamızda ise hastaların \% 75 'inde idrar analizi normaldi. Yine Bayram ve ark.'nın [22] çalışması ile korele olarak çalışmamızda karın ağrısı şikayeti ile başvurduktan sonra böbrek kisti tanısı alan 11 hasta (\%23) tanımlandı. Başvuru şikayeti olmaksızın farklı endikasyonlar nedeni ile yapılan US sonucunda basit böbrek kisti tanısı alan 29 hasta $(\% 60)$ saptandı. Bayram ve ark.'nın [22] 
çalışmasında bu oran \%31 olarak verilmiştir. Bizim çalışmamızdaki bu yüksek oran, devlet hastanesi US istem endikasyonlarının üniversite hastanesine oranla daha geniş olması ile ilişkili olabilir.

Çocuklarda basit böbrek kisti ve nefrolitiazis ilişkisi ile ilgili bir çalışma bulunmamakla beraber özellikle erişkinlerde böbrek taşlarının basit böbrek kistleri için risk faktörü olabileceğini iddia eden araştırmalar mevcuttur [24, 25]. Çalışmamızda 5 hastada gerilemiş nefrolitiazis öyküsü, 6 hastada ipsilateral tarafta kalkül mevcut idi. İpsilateral tarafta kalkül saptanan hastaların 3'ünde eşlik eden hematüri, 3'ünde hematüri ve piyüri eşlik etmekteydi. Çocuk yaş grubunda böbrek taşları dahil olmak üzere basit böbrek kisti oluşumu için risk faktörü olabilecek etmenler daha geniş vaka grupları ile değerlendirilmelidir.

Yine erişkinlerde basit böbrek kistleri ile hipertansiyon ve bozulmuş renal fonksiyon ilişkisini gösteren çalışmalar mevcuttur [26-28]. Eroğlu ve ark.'nın [8] çalışmasında da çocuk hastaların \%22'sinde basit böbrek kistine eşlik eden nedeni açıklanamayan böbrek fonksiyon bozukluğu olduğu görülmüş ve bu hastalara uzun dönem takip önerilmiştir. Çalışmamızda hastaların böbrek fonksiyonları normal olarak değerlendirilmiş, obezitesi olan 2 hasta basit böbrek kistine eşlik eden hipertansiyon tanısı almıştır.

Basit böbrek kistleri ile ayırıcı tanıya giren önemli bir kistik böbrek hastalığı ODPKB hastalığıdır. Rediger ve ark.'nın [16] yaptığı tek merkezli retrospektif bir çalışmada $10 \mathrm{yıl}$ boyunca böbrek kisti nedeni ile izlenen 87 hastanın \%12,6'sı ortalama 2,2 yıl izlem sonrası ODPKB hastalığı tanısı almıştır. İzlemde tanı alan 11 hastanın 4'ünde aile öyküsü tariflenmemiştir [16]. Çalışmamızda takiplerinin 11. ve 23. aylarında ODPKB hastalığı tanısı alan ve çalışma dışı bırakılan 2 hastada aile öyküsü yok idi.

Çalışmamızda evre 1 ve evre 2 böbrek kisti tanısı ile izlenen 48 çocuk hastanın ortalama $29,72 \pm 17,63$ ay izlemi esnasında malign dönüşüm görülmedi ve cerrahi endikasyon gelişmedi. Wang ve ark.'nın [2] yaptığı pediyatrik nefrolog ve ürologların da dahil edildiği bir anket çalışmasında böbrek kist takip aralığı pediyatrik nefrologlar tarafından ağırlıklı olarak 1 ila 2 yılda bir, pediyatrik ürologlar tarafından ise ağırlıklı olarak 6-12 ayda 1 olarak cevaplanmıştır. Çalışmamızda takip aralığı 6 ayda 1 olarak yapılmıştır.

Tek merkezli olması, retrospektif olması ve dosya taramalarında kist çapında artış hızının incelenmemiş olması çalışmamızın kısıtlılıklarıdır. Ayrıca MR görüntülemelerinde teyid edilmelerine rağmen, septasyonlar için renal doppler US ve kalsifikasyonlar için BT görüntülemesi yapılmamış olması çalışmanın kısıtlılıklarından biridir.

Sonuç olarak, ayrıntılı bir ultrasonografik inceleme ile tanı alabilecek evre 1 ve evre 2 basit böbrek kistlerinde; malign dönüşüm ve cerrahi endikasyon gerekliliği nadiren görülse de takiplerinde evre artışı, ODPKB hastalığı, hipertansiyon ya da böbrek fonksiyon bozukluğu gibi ortaya çıkabilecek durumlar nedeni ile mutlaka izlem gereklidir.

Çıkar ilişkisi: Yazar çıkar çatışması olmadığını beyan etmektedir.

\section{Kaynaklar}

1. Karmazyn B, Tawadros A, Delaney LR, et al. Ultrasound classification of solitary renal cysts in children. J Pediatr Urol 2015;11:149.e1-6 https://doi. org/10.1016/j.jpurol.2015.03.001

2. Wang ZTP, Chan EP, Moreno NV, et al. What to Do With Renal Cysts in Children? Urology 2020;140:138142. https://doi.org/10.1016/j.urology.2020.03.001

3. O'Kelly F, McAlpine K, Abdeen N, Keays MA, Leonard MP, Guerra LA. The prevalence, clinicodemographics, and outcomes of incidental and symptomatic renal cysts in a pediatric cohort undergoing ultrasonography. J Urol 2019;202:394-399. https://doi.org/10.1097/ JU.0000000000000264

4. Eknoyan G. A clinical view of simple and complex renal cysts. J Am Soc Nephrol 2009;20:1874-1876. https:// doi.org/10.1681/ASN.2008040441

5. McHugh K, Stringer DA, Hebert D, Babiak CA. Simple renal cysts in children: diagnosis and follow-up with US. Radiology 1991;178:383-385. https://doi.org/10.1148/ radiology.178.2.1987597

6. Koutlidis N, Joyeux L, Mejean N, Sapin E. Management of simple renal cyst in children: French multicenter experience of 36 cases and review of the literature. J Pediatr Urol 2015;11:113-117. https://doi.org/10.1016/j. jpurol.2015.03.003 
7. Cramer MT, Guay Woodford LM. Cystic kidney disease: a primer. Adv Chronic Kidney Dis 2015;22:297-305.

8. Eroglu FK, Kargın Çakııı E, Can G, et al. Retrospective analysis of simple and stage II renal cysts: pediatric nephrology point of view. Pediatr Int 2018;60:10681072. https://doi.org/10.1111/ped.13714

9. Wallis MC, Lorenzo AJ, Farhat WA, Bagli DJ, Khoury AE, Pippi Salle JL. Risk assessment of incidentally detected complex renal cysts in children: potential role for a modification of the Bosniak classification. J Urol 2008;180:317-321. https://doi.org/10.1016/j. juro.2008.03.063

10. Flynn JT, Kaelber DC, Baker Smith CM, et al. Subcommittee On Screening And Management Of High Blood Pressure In Children. Clinical practice guideline for screening and management of high blood pressure in children and adolescents. Pediatrics 2017;140:e20171904. https://doi.org/10.1542/ peds.2017-1904

11. Schwartz GJ, Munoz A, Schneider MF, et al. New equations to estimate GFR in children with CKD. J Am Soc Nephrol 2009;20:629-637. https://doi.org/10.1681/ ASN.2008030287

12. Tada S, Yamagishi J, Kobayashi H, Hata $Y$, Kobari T. The incidence of simple renal cyst by computed tomography. Clin Radiol 1983;34:437-439. https://doi. org/10.1016/s0009-9260(83)80238-4

13. Skolarikos A, Laguna MP, de la Rosette JJ. Conservative and radiological management of simple renal cysts: a comprehensive review. BJU Int 2012;110:170-178. https://doi.org/10.1111/j.1464-410X.2011.10847.x

14. Bosniak MA. The current radiological approach to renal cysts. Radiology 1986;158:1-10. https://doi. org/10.1148/radiology.158.1.3510019

15. Blazer S, Zimmer EZ, Blumenfeld Z, Zelikovic I, Bronshtein M. Natural history of fetal simple renal cysts detected in early pregnancy. J Urol 1999;162:812814. 10.1097/00005392-199909010-00066

16. Rediger C, Guerra LA, Keays MA, et al. Renal cyst evolution in childhood: a contemporary observational study. J Pediatr Urol 2019;15:188.e1-6.

17. Adachi T, Nakatani T, Minami H, et al. Renal cell carcinoma with hemorrhagic cyst formation in a 4-year-old boy. Int J Urol 2003;10:267-270. https://doi. org/10.1046/j.1442-2042.2003.00616.x

18. Kadekawa K, Miyazato M, Saito $S$, et al. Renal cell carcinoma originating in a renal cyst in a 12-yearold girl. J Pediatr Surg 2009;44:e5-7. https://doi. org/10.1046/10.1016/j.jpedsurg.2009.08.022

19. Henske EP, Thorner P, Patterson K, Zhuang $Z$, Bernstein J. Renal cell carcinoma in children with diffuse cystic hyperplasia of the kidneys. Pediatr Dev Pathol 1999;2:270-274. https://doi.org/10.1007/ s100249900123
20. Peng Y, Jia L, Sun N, et al. Assessment of cystic renal masses in children: comparison of multislice computed tomography and ultrasound imaging using the Bosniak classification system. Eur J Radiol 2010;75:287-292. https://doi.org/10.1016/j.ejrad.2010.05.035

21. Saltzman AF, Carrasco Jr. A, Colvin AN, Meyers ML, Cost NG. Can a modified Bosniak classification system risk stratify pediatric cystic renal masses? J Urol 2018;200:434-439. 10.1016/j.juro.2018.03.076

21. Bayram MT, Alaygut D, Soylu A, Serdaroğlu E, Cakmakcı $\mathrm{H}$, Kavukçu S. Clinical and radiological course of simple renal cysts in children. Urology 2014;83:433437. https://doi.org/10.1016/j.urology.2013.08.055

22. Simms RJ, Ong AC. How simple are 'simple renal cysts'? Nephrol Dial Transplant 2014;29:106-112. https://doi.org/10.1093/ndt/gfu106

23. Garcia Nieto V, Dublan Garcia K, Luis Yanes MI. Are simple renal cysts another manifestation of prelithiasis in infancy? Nefrologia 2010;30:337-341. https://doi. org/10.3265/Nefrologia.pre2010.Apr.10409

24. Chang CC, Kuo JY, Chan WL, et al. Prevalence and clinical characteristics of simple renal cyst. J Chin Med Assoc 2007;11:486-491. https://doi.org/10.1016/ S1726-4901(08)70046-7

25. Chin HJ, Ro H, Lee HJ, Na KY, Chae DW. The clinical significances of simple renal cyst: is it related to hypertension or renal dysfunction? Kidney Int 2006;70:1468-1473. https://doi.org/10.1038/ sj.ki.5001784

26. Lee $\mathrm{CT}$, Yang YC, Wu JS, et al. Multiple and large simple renal cysts are associated with prehypertension and hypertension. Kidney Int 2013;83:924-930. https:// doi.org/10.1038/ki.2012.481

27. Al Said J, Brumback MA, Moghazi S, Baumgarten DA, O'Neill WC. Reduced renal function in patients with simple renal cysts. Kidney Int 2004;65:2303-2308. https://doi.org/10.1111/j.1523-1755.2004.00651.x

Etik kurul onayı: Çalışma, Bursa Şehir Hastanesi Etik Kurulu'nun 17.02.21 tarih ve 2021-3/16 nolu kararı ile onay almıştır. 